\title{
Identify and Test the Resistance of Bacteria on Dental Unit Surfaces in Dental Clinic of Dentistry Faculty, Andalas University Padang
}

\author{
Alifia Aura Syafira*, Mustafa Noer, DDS, MS, Syafrawati, M. Common Health Sc \\ Microbiology, Faculty of Dentistry, Universitas Andalas, Padang 25128, Indonesia \\ *E-mail: alifiaauras@gmail.com
}

\begin{abstract}
Objective: Cross infection is one of the problems in dentistry. It can be caused by dental unit surfaces which act as the mediator for bacteria to enter the body. The aim of this research was to identify and test the resistance of bacteria that found on dental unit surfaces which suspected to be contaminated by patients in Dental Clinic.

Methods: Using simple random sampling method, this research observed 15 samples of handle, instruments table and spittoon bowl surfaces. Bacterial contamination identified and tested for its resistance in Microbiology Laboratory of Faculty of Medicine, Andalas University. Amoxicillin, amoxicillin-clavulanic acid combination, chloramphenicol, erythromycin, gentamycin, tetracycline, ciprofloxacin and cefoperazone discs were used for resistance test of bacteria.

Results: There were 16 contaminations of bacteria found. 12 of them were gram-positiveBacillus spand remaining four were gram-negative bacilli which are Enterobacteriaceae, Pseudomonas aeruginosa, and two Klebsiella sp. The resistance test showed that Pseudomonas aeruginosa is resistant to amoxicillin, amoxicillin-clavulanic acid combination, chloramphenicol, and erythromycin while both of Klebsiella sp are resistant to amoxicillin, amoxicillinclavulanic acid combination, chloramphenicol, and erythromycin.
\end{abstract}

Conclusion: Dental unit surfaces are an important vehicle for resistance bacteria to spread.

Keywords: antibiotics, bacteria contamination, cross infection, dental unit surfaces, resistant

\section{Introduction}

Infectious disease is a disease that caused by microorganisms, such as bacteria; viruses; fungi; prion; and protozoa which enter the body, multiply and damage the tissue and organs. Microorganisms which are capable of causing a disease are called pathogens. ${ }^{1}$ This pathogen could be transmitted from one to another person, either by direct contact with humans and animals or by indirect contact with objects of the environment, such as, equipment or instruments and surfaces which act as a reservoir for pathogens to live and survive. Cross infection is the name of infectious disease that spreads from one person to another. ${ }^{2}$

Risk of infectious disease to be spread in dental practice is high. It can happen because the majority of dentist's activities, in case of treatment or simply diagnosing a patient, force them to make a contact with pathogens in the saliva of the patient and their blood. ${ }^{3}$ Object of environment in dental practice that has high risk to be a reservoir for bacteria to live, survive and multiply is dental unit. Dental unit is equipment for a dentist to cure the oral health of a patient. The dental unit consists of a dental chair, instrument tray or table, and spittoon bowl which continuously touched and contaminated by bacteria which were carried by patients. The bacteria could enter the body through small cuts in skin or through finger nails of people who has touched it. ${ }^{1}$

When this study was held around April 2015, Dental Clinic of Faculty of Dentistry in Andalas University used 23 dental units. Based on interviews that author has done with students and cleaning services of the dental clinic, cleaning dental unit thoroughly was done only after last work on that day. This kind of act did not recommend by the standard of infection control in Dental Clinic and Practice. Miller and Palenik have told in their book that cleaning work environments such as dental unit surface must be rinsed between patients or cover surfaces with plastic wrap and change it for every patient. ${ }^{1}$

Poor infection control is one of the reason for bacteria which resistant to anti-microbes spread. ${ }^{4}$ The presence of bacteria resistance will cause huge disadvantages in the world of health, like pathogens will not only resistant to one type of antibiotic but various type of antibiotics then it will make treatment processes harder and more expensive. ${ }^{5}$ 
Beside poor infection control, bacteria resistance also could exist cause of the way antibiotics have been used.5 Inadequate dose of antibiotics will lead micro-flora on the body become imbalance. Thus, antibiotics will only kill sensitive microorganisms, while resistant bacteria will multiply itself continuously. ${ }^{6}$

Hadi on his book, told that one of strategic to control presence of bacteria resistance is by doing surveillance of bacteria resistance, as an effort to prevent the existence of them.4 Surveillance reports that organized goodly will be useful as a basic to see the tendency which bacteria will be resistant soon and to make new specific principles according to the reports. ${ }^{4}$

That is why the surveillance about what type of bacteria could be found on handle of dental chair, instrument table, and spittoon bowl in Dental Clinic Faculty of Dentistry in Andalas University and how the resistance of its bacteria to many types of antibiotics that frequently used which are amoxicillin, amoxicillin-clavulanic acid combination, chloramphenicol, erythromycin, gentamycin, tetracyclin, ciprofloxacin and cefoperazone need to be done.

\section{Methods}

This study is a descriptive study that explained about species of bacteria which found on dental unit surfaces in Dental Clinic of Faculty of Dentistry in Andalas University and observed resistance of the bacteria to various type of antibiotics. This research started from February until April 2015 in Dental Clinic of Faculty of Dentistry in Andalas University and Microbiology Laboratory of Faculty of Medicine in Andalas University. There were 69 populations of handle, instrument table and spittoon bowl surfaces in Dental Clinic of Andalas University. According to the formula of observational research, 15 samples were obtained.

The surfaces of handle, instrument table and spittoon bowl were swabbed by sterile cotton stick then placed it into medium transport with tyoglicolic acid. ${ }^{7}$ Cotton sticks with bacteria in it were brought to Microbiology Laboratory of Faculty of Medicine of Andalas University to culture it for 24 hours. Then by using streak plate method, gram staining and with the help of a microscope, we observed its genus. If the genuses of bacteria are suspected as well-known pathogens, we continued to identify its species using biochemical test such as Triple Sugar Ion agar, Simmon's Citrate agar, and Semi Solid agar. $^{7}$ After its genus and species have identified, resistance test using 8 discs of antibiotic which are amoxicillin, amoxicillin-clavulanic acid combination, chloramphenicol, erythromycin, tetracyclin, gentamycin, ciprofloxacyn, and cefoperazone were conducted. ${ }^{8}$

\section{Results}

Research about identifying and test the resistance of bacteria which found on dental unit surfaces in Dental Clinic Faculty of Dentistry of Andalas University was done around February until April 2015 with swabbing 15 samples of handles of the dental chair, instrument trays and spittoon bowl surfaces. The result of swabbing surfaces was brought to Microbiology Laboratory of Medical Faculty in Andalas University to culture, identify and test the resistance of it.

The results of bacteria culture from 15 samples showed 16 species of bacteria. Under the microscope with 100x large scale, we found that among 16 bacterial contaminations, there were 12 gram-positive bacilli that form chains and other four were gram-negative bacilli that each one of it showed different features (Table 1)

Table 1. Culture results

\begin{tabular}{|c|c|c|}
\hline \multicolumn{3}{|c|}{ The Results of Culture Bacteria in Dental Unit Surfaces } \\
\hline No. & Specimen & Results \\
\hline 1 & Spittoon Bowl & Bacillus spp \\
\hline 2 & Instrument Tray & Bacillus spp \\
\hline 3 & Instrument Tray & Bacillus spp \\
\hline 4 & Handle of Dental Chair & Bacillus spp \\
\hline 5 & Instrument Tray & Enterobacteriaceae \\
\hline 6 & Handle of Dental Chair & Bacillus spp \\
\hline 7 & Spittoon Bowl & $\begin{array}{l}\text { Pseudomonas } \\
\text { aeruginosa }\end{array}$ \\
\hline 8 & Handle of Dental Chair & Klebsiella spp \\
\hline 9 & Instrument Tray & Bacillus spp \\
\hline 10 & Handle of Dental Chair & Bacillus spp \\
\hline 11 & Spittoon Bowl & Bacillus spp \\
\hline 12 & Handle of Dental Chair & Bacillus spp \\
\hline 13 & Spittoon Bowl & Bacillus spp \\
\hline 14 & Instrument Tray & Bacillus spp \\
\hline 15 & Spittoon Bowl & Klebsiella spp \\
\hline
\end{tabular}

Through characteristics of 12 gram-positive bacilli that form chains, we sure that it was Bacillus spp (Figure 1). 


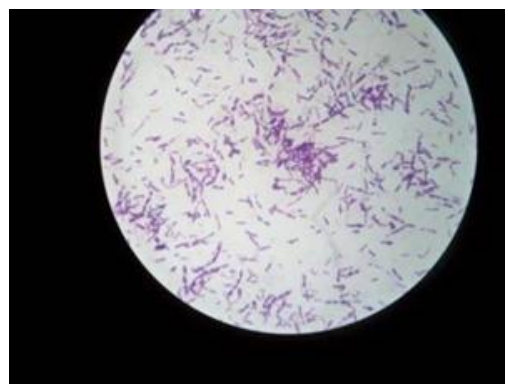

Figure 1. Bacillus spp under microscope. (Coloringpurple after gram staining and form chains)

Remaining four gram negative bacilli which colored red in gram staining, then biochemical test was done to make sure its species. Biochemical test that has been done showed that gram-negative bacilli which was found in instrument tray was Enterobacteriaceae, in spittoon bowl was Pseudomonas aeruginosa, in handles of dental chair was Klebsiella spp, and in other spittoon bowl was another Klebsiella spp (Figure 2 and Table 2).

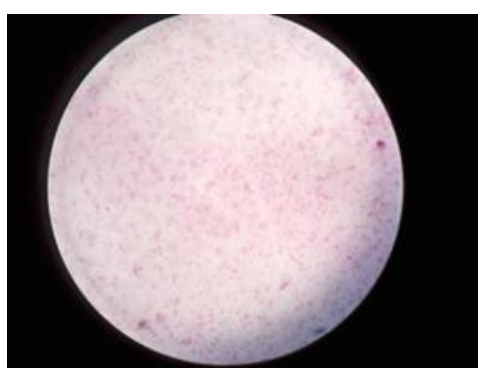

Figure 2. Microscope. Gram negative bacteria under (Coloring red after gram staining)

Table 2. Biochemical test

\begin{tabular}{|c|c|c|c|c|}
\hline \multirow[b]{2}{*}{ BT } & \multicolumn{3}{|c|}{ Dental Unit Surfaces } & \multirow[b]{2}{*}{ Spittoon Bow } \\
\hline & $\begin{array}{c}\text { Handle } \\
\text { chair }\end{array}$ & Spittoon Bowl & $\begin{array}{c}\text { Instrument } \\
\text { Tray }\end{array}$ & \\
\hline \multirow{3}{*}{ TSI* } & $\mathrm{A} / \mathrm{A}$ & $\mathrm{K} / \mathrm{K}$ & $\mathrm{A} / \mathrm{A}$ & $\mathrm{A} / \mathrm{A}$ \\
\hline & Gas + & Gas + & Gas + & Gas + \\
\hline & $\mathrm{H} 2 \mathrm{~S}-$ & $\mathrm{H} 2 \mathrm{~S}-$ & $\mathrm{H} 2 \mathrm{~S}-$ & $\mathrm{H} 2 \mathrm{~S}-$ \\
\hline SS* & + & + & - & - \\
\hline $\mathrm{SC}^{*}$ & - & + & + & + \\
\hline
\end{tabular}

The bacteria produce $\mathrm{H} 2 \mathrm{~S}$ and gas or not. A/A means bacteria produce acid, and $\mathrm{K} / \mathrm{K}$ means bacteria produce alkali. *SS: Semi Solid Agar is an agar which was used to test whether the bacteria are some motile bacteria or not motil. *SC: Simmon's Citrate Agar is an agar to see if citrate is the only source of carbon for the bacteria or not.

Results of resistance test of thus bacteria showed that Enterobacteriaceae was sensitive to all types of antibiotics that used which are amoxicillin, amoxicillin-clavulanic acid combination, chloramphenicol, erythromycin, gentamycin, tetracyclin, ciprofloxacin, and cefoperazone (Figure 3; Table 3)

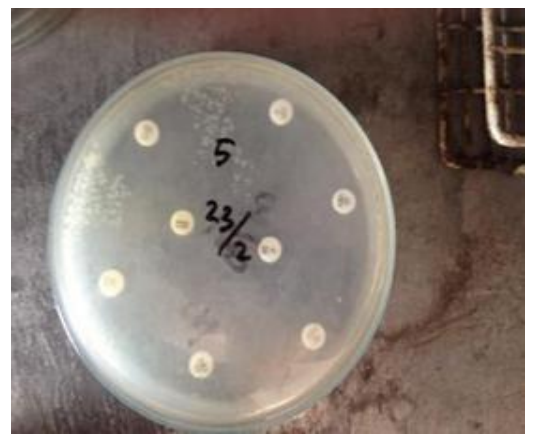

Figure 3. Result of Enterobacteriaceae resistance test. (sensitivity zone was formed around antibioticdiscs)

Table 3. Enterobacteriaceae Resistance Test Result

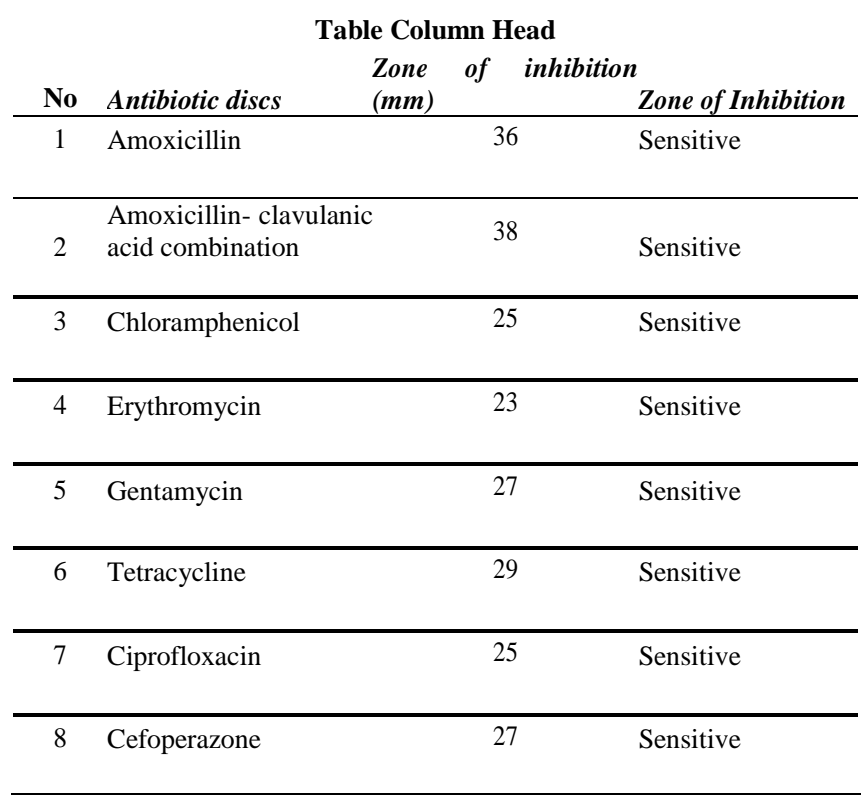

Pseudomonas aeruginosa resistance test showed that itwas resistant to amoxicillin, amoxicillin-clavulanic acid combination, chloramphenicol, and erythromycin. It showed intermediate zone for tetracyclin and sensitive to gentamycin, ciprofloxacin and cefoperazone (Figure 4; Table 4).

*TSI: Triple Sugar Ion Agar is an agar which was used to do glucose, lactose and fructose test, also to see whether 


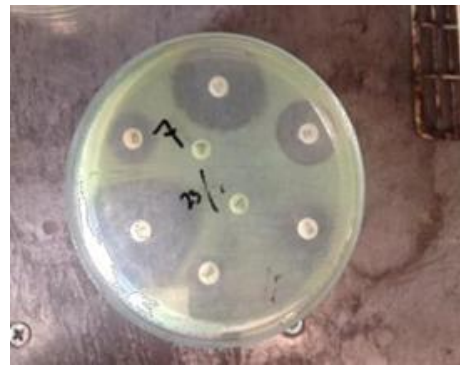

Figure 4. Result of Pseudomonas aeruginosa Resistance Test. (sensitivity zone wasformed around antibiotic discs)

Table 4. Pseudomonas aeruginosa Resistance Test Result

\begin{tabular}{cccl} 
& \multicolumn{3}{c}{ Resistance Test } \\
\cline { 2 - 4 } No & Antibiotic discs & $\begin{array}{c}\text { Zone of inhibition } \\
(\mathbf{m m})\end{array}$ & Zone of Inhibition \\
\hline 1 & Amoxicillin & 0 & Resistant
\end{tabular}

\begin{tabular}{llll}
\hline $2 \begin{array}{l}\text { Amoxicillin- } \\
\text { clavulanic combination }\end{array}$ & Acid 0 & Resistant \\
\hline
\end{tabular}

\begin{tabular}{llll}
\hline 3 & Chloramphenicol & 10 & Resistant \\
\hline 4 & Erythromycin & 13 & Resistant \\
\hline 5 & Gentamycin & 21 & Sensitive \\
\hline
\end{tabular}

\begin{tabular}{llll}
\hline 6 & Tetracycline & 16 & Intermediate \\
\hline 7 & Ciprofloxacin & 34 & Sensitive \\
\hline 8 Cefoperazone & 30 & Sensitive
\end{tabular}

Klebsiella spp in handle of dental chair and spittoon bowlsurfaces showed that they were resistant to amoxicillin, amoxicillin-clavulanic acid combination, chloramphenicol, and erythromycin with different measurements of each formed zone. They were sensitive to gentamycin, tetracyclin, ciprofloxacin and cefoperazone, also with different sizes of each formed zone (Figure 5 and 6; Table 5 and 6 ).

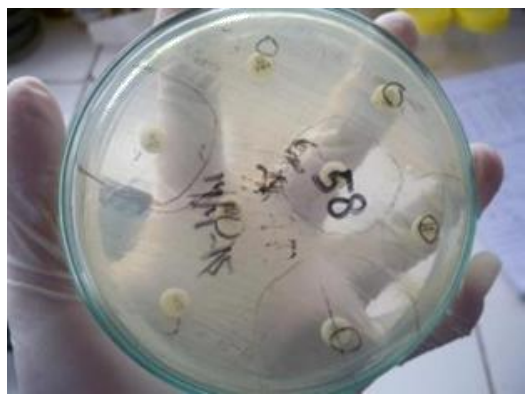

Figure 5. Klebsiella spp Resistance Test Result. (sensitivity zone was formed around antibioticdiscs)

Table 5. Klebsiella spp Resistance Test Result

\begin{tabular}{clcc}
\hline \multicolumn{4}{c}{ Resistance Test } \\
\hline No & Antibiotic discs & $\begin{array}{c}\text { Zone } \text { of } \text { inhibition } \\
(\mathbf{m m})\end{array}$ & \multicolumn{2}{c}{ Zone of Inhibition } \\
\hline 1 & Amoxicillin & 0 & Resistant \\
\hline 2 & $\begin{array}{l}\text { Amoxicillin-clavulanic } \\
\text { combination }\end{array}$ & Acid 0 & Resistant \\
\hline 3 & Chloramphenicol & 0 & Resistant \\
\hline 4 & Erythromycin & 0 & Resistant \\
\hline 5 & Gentamycin & 26 & Sensitive \\
\hline 6 & Tetracycline & 23 & Sensitive \\
\hline 7 & Ciprofloxacin & 32 & Sensitive \\
\hline 8 & Cefoperazone & 29 & Sensitive \\
\hline
\end{tabular}

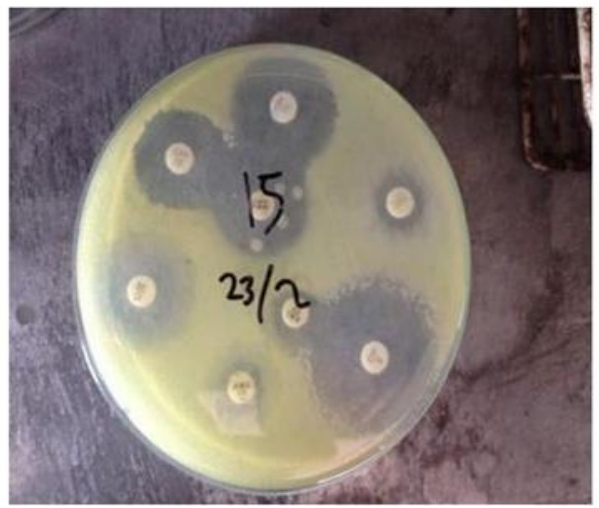

Figure 6. Result of Klebsiella spp resistance test. (sensitivity zone was formed around antibioticdiscs)

Table 6. Klebsiella spp resistance test result

\begin{tabular}{|c|c|c|c|}
\hline \multicolumn{4}{|c|}{ Resistance Test } \\
\hline No & Antibiotic discs & Zone of inhibition (mm) & Zone of Inhibition \\
\hline 1 & Amoxicillin & 11 & Resistant \\
\hline 2 & $\begin{array}{l}\text { Amoxicillin- clavulanic } \\
\text { combination }\end{array}$ & Acid 10 & Resistant \\
\hline
\end{tabular}




\begin{tabular}{llcl}
3 & Chloramphenicol & 10 & Resistant \\
\hline 4 & Erythromycin & 11 & Resistant \\
\hline 5 & Gentamycin & 24 & Sensitive \\
\hline 6 & Tetracycline & 22 & Sensitive \\
\hline 7 & Ciprofloxacin & 28 & Sensitive \\
\hline 8 & Cefoperazone & & Sensitive \\
\hline
\end{tabular}

ESBL producing Klebsiella spp to appear in dental clinic is still needed.

Then, Enterobacteriaceae found on one dental unit surface. Enterobacteriaceae or Coliform is a family of gram negative bacteria which supposed to live in gastrointestinal tract of humans and animals. The characteristics of Enterobacteriaceae are motile with peritrichous flagella, facultative anaerobic, produce gas, also gives positive to catalase test. ${ }^{9}$ Along with Staphylococcus and Streptococcus, Enterobacteriaceae is family of bacteria which commonly causes diseases to humans, like bacteremia, pneumonia, and hospitalacquired urinary tract infection. ${ }^{9,12}$ If it appears on the

\section{Discussions}

Results of identifying bacterial contaminations in dental unit surfaces are 12 gram-positive Bacillus spp and four gram negative bacteria which are Enterobacteriaceae,

Pseudomonas aeruginosa and two Klebsiella spp. Bacillus spp is saprophyte gram positive bacteriawhich usually found in water, soil and air. Bacillusspp could live for years or longer in environments by creating spora ${ }^{9}$

That is why in almost every surface, if it wasn't cleaned well and correct, Bacillus spp would be found easily. Also, it is an aerob bacteria and form chains. Resistance test wasn't done to Bacillus spp because majority of genus and species related to Bacillus hasn't caused any disease to humans. ${ }^{9}$

Klebsiella spp was found on two samples of dentalunit surfaces. Klebsiella spp is one of the species bacteria of enteric bacteria. The differences between Klebsiella spp with another enteric bacteria areKlebsiella species shows mucoid growth with huge polysaccharide capsule and it isn't motil. It gives positive result to decarboxylase and citric test. Klebsiella spp is one of bacterial pathogens which cause nosocomial infections, such as pneumonia bacterial, urinary tract infection and bacteremia. ${ }^{9}$

Extended-Spetrum- $\beta$-Lactamases-producing Klebsiella pneumonia has known to spread all over theworld cause diseases becoming harder to cure. It happens because ESBL-producing Klebsiella spp already resistant to all ranges of $\beta$-lactam antibiotics including penicillin (amoxicillin etc) and cephalosporine. This enzym can be easily transferred from one species gram-negative bacteria to another.10 In this research, both of Klebsiella spp that found were resistant to amoxicillin, amoxicillin-clavulanic acid combination, chloramphenicol and erythromycin, but they were sensitive to gentamycin, tetracycline, ciprofloxacin and cefoperazone. Even though it was resistant to amoxicillin and amoxicillin-clavulanic acid combination, it was sensitive to cefoperazone which is one of 3rd generations of cephalosporine which is also $\beta$ lactam antibiotics. ${ }^{9}$ Therefore, Klebsiella sppthatwere found on dental unit surfaces in Dental Clinic of Andalas University was not one of ESBL producing Klebsiella, but although it isn't one of those, preventing the tendency of other places which it is supposed to live, such as in urinary tract, abdomen, blood vessels, prostate gland, pulmonary, bone and meninges, it will cause diseases. ${ }^{9}$ The appearance of ESBL-producing Enterobacteriaceae also has widely known in the world of health, but result of resistance test that had done to Enterobacteriaceae in this study was satisfying. They were sensitive to all antibiotic discs that used.

Pseudomonas aeruginosa which was found on one ofdental unit surfaces in Dental Clinic of Andalas University is an issue. Since it is already known as the main pathogen for humans in Pseudomonads family and one of most important nosocomial pathogens because it dominates in all hospital-acquire diseases such as pneumonia with symptoms of productive coughing, cyanosis, tremble and out of breath. ${ }^{11}$ Pseudomonas aeruginosa, also with other important pathogens, such as, Clostridium difficile, meticillin-resistant Staphylococcus aureus (MRSA), vancomycin-resistant Enterococci (VRE),

Actinobacter baumanii, and norovirus have ability tosurvive in dry surfaces environment, which may then become source for transmission. ${ }^{12}$ The presence of Pseudomonas aeruginosa in humid surfaces inhospital means those surfaces needed to be cleaned thoroughly., ${ }^{9,13}$

The features of Pseudomonas aeruginosa are widely found in soil and water, also it is usually found in intestine and human skins. They were obligate aerob, motil, bacil, produce smell of grape and agar will turn to blue or green if there is Pseudomonas aeruginosa in it. If there is an abnormality in the immune system of human body, these bacteria will easily cause diseases. ${ }^{9}$ Permeability of their outer membrane are 12-100 times lower than any other gram negative bacteria which already known to have low permeability of outer membrane. ${ }^{13,14}$ That is why, multidrug-resistant Pseudomonas aeruginosa is no longer a rare thing. In this research, Pseudomonas aeruginosa that was found was ESBL-class C-producing Pseudomonas aeruginosa because it was resistant to clavulanic acid as beta lactamase inhibitor. ${ }^{10}$

Several supporting studies have identified presence of colonization or infection patients because surfaces of health-care settings, especially in dental offices..$^{12,15,16}$ 
Kurita, Kurashina and Honda have identified the presence of MRSA in surfaces of water-syringe and reclining dental chair. There were 8 of 140 patients which have been treated in those dental chairs was positively got infected or only colonized by meticillin-resistant Staphylococcus aureus.15Other study about evaluation of environmental bacterial contamination and procedures to control cross infection in a sample of Italian Dental Surgeries by Monarka et all showed that there were 9,8\% Staphylococcus aureus and 13,7\% $\beta$-hemolyticus Streptococci was found on five instrument trolleys. ${ }^{16}$

\section{Conclusions}

There were 16 contaminations of bacteria were found in 15 samples of handle of dental chair, instrument table and spittoon bowl surfaces in Dental Clinic of Andalas University which usually serves many patients with various type of microorganisms that were carried by them. Among 16 contaminations that found, there were 12 gram-positive Bacillus spp and four gram negative bacteria which are Enterobacteriaceae, Pseudomonasaeruginosa and two Klebsiella spp. Good things that were found are mostly bacteria were 12 grampositive Bacillus spp that well known as not pathogens forhumans. Also, Enterobacteriaceae that was found, although it is known as pathogens for humans, it isn't resistant to any antibiotics that used for resistance test. The problems are the presence of two Klebsiella spp and Pseudomonasaeruginosa in dental unit surfaces. Besides, they are known as leading pathogens in many hospitalacquired diseases, they were also found resistant to amoxicillin, amoxicillin-clavulanic acid combination, chloramphenicol and erythromycin that commonly used in dentistry.

This research has shown that even when we aren't working in general hospital, if cleaning surfaces hasn't become a serious concern, and lack of monitoring use of antibiotics that doctor or dentist prescribed, bacteria resistance could spread easily. We hope that surveillance of bacteria resistance would be done continuously in another dental clinic as one of effort to prevent bacteria resistance to spread any wider.

After all, this research also has many of deficiencies which hopefully another researcher ahead will complete all the drawbacks that we have made, such as samples that we used is not enough to represent all dental clinic of other university in Indonesia and also we have not perfectly identified Enterobacteriaceae family into specific genus and species, whether it was Salmonella, Escherichia or Klebsiella, because lack of biochemical test that we could do.

Finally, author suggests for further research to identify possibility of bacteria resistance to appear in another surfaces or equipment in dental clinic or even the hands of dental practitioner and find out what is best disinfectant to use for cleaning surfaces and equipment in dental clinic completely.

\section{References}

1. Miller CH, Palenik CJ. Infection Control and Management of Hazardous Materials for the Dental Team. (4 $4^{\mathrm{th}}$ ed.). Canada: Mosby; 2010:26-33;84-103

2. Dougherty L, Lister S. The Royal Marsden Hospital Manual of Clinical Nursing Procedures, Student Edition, Ed 8. London: Blackwell Publishing Ltd, 2011:93-99

3. Kusmawan RA. Infeksi Nosokomial di Klinik Gigi. $\left(2^{\text {nd }}\right.$ ed.). Skripsi. Medan: Fakultas Kedokteran Gigi Universitas Sumatera Utara, 2008: 1-7

4. Hadi U. Buku Ajar Ilmu Penyakit Dalam Jilid 3. ( $5^{\text {th }}$ ed. ). Jakarta: Interna Publishing; 2009: 2896-2905

5. Utami ER. Antibiotika, Resistensi, dan Rasionalitas Terapi. Saintis. 2012; 1(1): 124-138

6. Pedersen GW. Buku Ajar Praktis Bedah Mulut. ( $1^{\text {st }}$ ed.). Jakarta: EGC; 2013: 191-207

7. Samanarayake LP. Essential Microbiology for Dentistry, Ed Philadelphia: Saunders Company; 2002 p. 38-47, 53-59.

8. Reynolds J. Kirby-Bauer Test for Antibiotic Susceptibility. Richland College: BIOL2421, 2011: 1-4

9. Brooks GF, Jawetz E, Butel JS, Melnick JL, Ornston LN, Adelberg EA. Mikrobiologi Kedokteran. (25 th $e d$.$) . Jakarta:$ EGC; 2013 p. 154, 173-176, 223-238, 239-242

10. Satari, Mieke H. Multidrugs Resistance (MDR) Bakteri terhadap Antibiotik. FKG Universitas Padjajaran. 2012 Juni:1-7 [In Indonesia]

11. Yuwono. Mikrobiologi Kedokteran. Modul Mikrobiologi FKG Universitas Sriwijaya. 2012:88-89 [In Indonesia]

12. Otter JA, Yezli S, French GL. The Role Played by Contaminated Surfaces in the Transmission of Nosocomial Pathogens. Infect Control Hosp Epidemiol. 2011; 23(7): 686-699

13. Peleg AY, Hooper DC. Hospital-Acquired Infections Due to Gram-Negative Bacteria. $N$ Engl J Med. 2010;362(19):1804-1813

14. Hancock REW. Resistance Mechanisms in Pseudomonas aeruginosa and Other Nonfermentive Gram-Negative Bacteria. Med Microbiol. 1998;27(1):S93-S99

15. Kurita H, Kurashina K, Honda T. Transmission of MRSA via Dental Operatory Surfaces. Br Dent J. 2006; 201(5):

16. Monarca S, Grottolo M, Renzi D, Paganelli C, Sapelli P, Zerbini I, Nardi G. Evaluation of Environmental Bacterial Contamination and Procedures to Control Cross Infection in a Sample of Italian Dental Surgeries. Occup Environ Med. 2000; 57: 721-726 